\title{
Association of nucleolar organizing regions and Ki-67 expression with recurrence rate of hair follicle tumor in dogs
}

\author{
[Associação das regiões organizadoras de nucléolos e da expressão do Ki-67 com a taxa de recorrência \\ dos tumores de folículo piloso em cães] \\ P.C. Souza ${ }^{1}$, N.M. Ocarino ${ }^{2}$, W.L.F. Tavares ${ }^{3}$, J.N. Boeloni ${ }^{2}$, G.D. Cassali ${ }^{3}$, R. Serakides ${ }^{4} *$ \\ ${ }^{1}$ Faculdade de Medicina Veterinária e Zootecnia - USP - São Paulo, SP \\ ${ }^{2}$ Aluna de pós-graduação - EV-UFMG - Belo Horizonte, MG \\ ${ }^{3}$ Instituto de Ciências Biológicas - UFMG - Belo Horizonte, MG \\ ${ }^{4}$ Escola de Veterinária - UFMG \\ Caixa Postal 567 \\ 30123-970 - Belo Horizonte, MG
}

\begin{abstract}
Mitotic index, nuclear diameter, number of nucleolar organizing regions, and Ki-67 expression, in hair follicle tumors of 82 dogs were evaluated. Tissue specimens were used to prepare sections for histological staining for number of nucleolar organizing region and immunohistochemical staining for Ki-67. Tumors were classified as trichoblastoma $(n=32)$, benign trichoepithelioma $(n=30)$, pilomatricoma $(n=7)$, malignant trichoepithelioma $(\mathrm{n}=6)$, infundibular keratinizing acanthoma $(\mathrm{n}=5)$, and tricholemmoma $(\mathrm{n}=2)$. Head, dorsum, and limbs were the most affected sites. Malignant trichoepithelioma presented significantly higher mitotic index, number of nucleolar organizing regions and Ki-67 expression. Regarding benign neoplasms, trichoblastoma presented significantly higher mitotic index and number of nucleolar organizing regions. Ki-67 expression did not differ among hair follicle benign neoplasms. Recurrence was only observed in two cases, with one benign trichoepithelioma and one malignant trichoepithelioma. In the two cases, nodules have not been removed with clean surgical margin. It was concluded that in benign neoplasms of hair follicles, the number of nucleolar organizing regions and Ki67 expression were significantly smaller than in malignant neoplasm. Clean surgical margins are suggested to be more responsible to tumor recurrences than the number of nucleolar organizing regions, expression of $\mathrm{Ki}-67$, and the mitotic index.
\end{abstract}

Keywords: dog, neoplasm, AgNOR, hair follicle, Ki-67

\section{RESUMO}

O objetivo deste trabalho foi avaliar o indice mitótico, o diâmetro nuclear, o número de regiões organizadoras de nucléolos e a expressão do Ki-67 em 82 tumores de foliculo piloso de cães, entre 2000 e 2006. Os tumores foram classificados como tricoblastoma $(n=32)$, tricoepitelioma benigno $(n=30)$, tricoepitelioma maligno $(n=6)$, pilomatricoma $(n=7)$, acantoma infundibular ceratinizante $(n=5)$ e tricolemoma $(n=2)$. A cabeça, o dorso e os membros foram os locais mais frequentemente acometidos. O tricoepitelioma maligno apresentou indice mitótico, número de regiões organizadoras de nucléolos e expressão do Ki-67 significativamente maiores quando comparado aos outros tipos de tumores. Dentre as neoplasias benignas, o tricoblastoma apresentou índice mitótico e número de regiões organizadoras de nucléolos significativamente maiores. A expressão do Ki-67 não diferiu entre os tumores benignos de foliculo piloso. A recorrência foi observada apenas em dois casos, incluindo um tricoepitelioma benigno e um tricoepitelioma maligno. Em dois casos, os nódulos não foram removidos com margem cirúrgica completa. Desta forma, conclui-se que nas neoplasias benignas de folículo piloso, o número das regiões organizadoras de nucléolo e da expressão de Ki-67 foram significativamente menores que em neoplasias malignas. Além disto, sugere-se que a margem cirúrgica

Recebido em 24 de outubro de 2007

Aceito em 2 de setembro de 2008

*Autor para correspondência (corresponding author)

E-mail: serakide@dedalus.lcc.ufmg.br

Apoio: FAPEMIG e CAPES (Edital pro-equipamentos 01/2007) 
completa está mais associada à recorrência dos tumores que as regiões organizadoras de nucléolo, a expressão de Ki-67 e o índice mitótico.

Palavras-chave: cão, neoplasma, Agnor, folículo piloso, Ki-67

\section{INTRODUCTION}

Skin tumors are among the most diagnosed dermatopathies in the USA according to a study carried out in 17 veterinary hospitals (Sischo et al., 1989). Skin neoplasms and hair follicle tumors represent, respectively, about $30 \%$ and $5 \%$ from the total of neoplasms diagnosed in dogs (Bostock, 1986; Walder and Gross, 1992; Goorman and Dobson, 1995).

According to the most recent classification, infundibular keratinizing acanthoma, pilomatricoma, trichoblastoma, trichoepithelioma, and tricholemmoma are tumors arising from hair follicles (Goldschmidt and Hendrick, 2002). Each one of these neoplasms presents distinct morphological features. Several neoplastic characteristics associated with recurrence and survival rate of patients have been studied in order to verify their relationship with prognosis in the cases of canine transmissible venereal tumor, canine mammary tumor, canine malign melanoma, canine lymphosarcoma, and canine mastocytomas. These characteristics are: clinical staging system (Bozlu et al., 2002), histological evaluation of clean surgical margins, number of mitoses/field (Greattu et al., 2004), nuclear diameter (Lohr et al., 1997), quantification of nucleolar organizing regions (NORs) (Orell et al., 1991; Bostock et al., 1992; Kiupel et al., 1999; Ceccarelli et al., 2000; Silva et al., 2006), and the immunohistochemical expression of cell proliferation, (Scase et al., 2006; Seguin et al., 2006) among others. The histochemical method to identify and quantify NORs has been used in several types of neoplasms, isolated or in association with $\mathrm{Ki}-67$ expression (Lohr et al., 1997). Good results were obtained when using NORs and Ki-67 to characterize and differentiate benign and malignant tumors (Hazan et al., 2002; Iqbal et al., 2002)

Frequency and morphological characteristics of hair follicle tumors are well documented (Goldschmidt and Hendrick, 2002). At present, however, there are no studies on the immunohistochemical expression of Ki-67 and the quantification of NORs in different types of neoplasms of hair follicle. Thus, the objective of this work was to study cases of hair follicle tumors in dogs, from 2000 to 2006. The number of mitoses, the nuclear diameter, the number of nucleolar organizing regions, and imunohistochemical expression of $\mathrm{Ki}-67$ of hair follicle tumors were studied and each one of these four variables was associated with the recurrence rate.

\section{MATERIAL AND METHODS}

From January 2000 to July 2006, all cases of hair follicle neoplasm diagnosed in the pathology sector of the veterinary hospital at the Universidade Federal de Minas Gerais were studied. In this period, the total number of canine neoplasms was determined, from which skin tumor and therefore hair follicle tumor frequencies were obtained.

Information on the animal (breed, gender and age) and on the tumor (location, mean nodule diameter, and growth time length - the running time from when the tumoral mass was first noticed to its surgical removal) were obtained from all 82 clinical cases of animals with hair follicle neoplasms. Neoplasms were also classified as simple or multicentric according to the number of nodules from the same neoplasm per animal. All animals underwent nodule surgical removal with at least $1 \mathrm{~cm}$ of surgical margin beyond the grossly visible tumor area. Histopathological evaluation of margins of all tumors was obtained using bread loaf-cross technique. Animals did not undergo any chemotherapeutic or radiotherapeutic treatment before or after surgery.

Tumors were fixed in neuter formalin at $10 \%$ and processed by the paraffin inclusion technique. Four micrometers histological sections were stained by hematoxylin-eosin technique (HE) for histological diagnoses. Tumors were classified as infundibular keratinizing acanthoma, benign or malignant pilomatricoma, trichoblastoma, benign or malignant trichoepithelioma, and tricholemmoma, according to the nomenclature proposed by the World Health Organization (Goldschmidt and Hendrick, 2002). In each of the 82 samples of hair follicle tumors, the mean number of mitoses/field, the mean nuclear diameter, the number of NOR, and the percentage of cells with $\mathrm{Ki}-67$ expression were determined. In each of these 82 samples, the mean number of mitoses/field was determined in 10 fields throughout the histological section with a $400 \times$ magnification. 
With an ocular containing a ruler, diameters (longitudinal and transversal) of 30 cellular nuclei were measured using the immersion objective (1000× magnification). In the end, values were converted to micrometers by using a micrometric slide.

Histological sections were impregnated with silver in order to individualize nucleolar organizer regions (NORs), in accordance with a described technique (Ploton, 1994) with some changes (Aubele et al., 1994). NORs counting was performed with an immersion objective (1000× magnification). NORs present in 50 nuclei of neoplastic cells were counted. The counting of the NORs was manually performed by the same operator. Only those NORs, which were individualized with black or brown dots, were counted. When clustered, they were considered as a single NOR.

The number of cells and fields was determined using the technique of studying mean value instability variation. Standard deviation and variation coefficient of the studied variables were stable in ten fields, 30 cells, and 50 nuclei for determining the number of mitoses, the mean nuclear diameter, and the number of NORs, respectively.

Histological sections of $4 \mu \mathrm{m}$ were also submitted to immunohistochemical analysis, using antiMIB-1. ${ }^{1} \quad$ Streptavidin-biotin-peroxidase ${ }^{2}$ and antigenic recovery techniques with the use of Retrieval solution ${ }^{3}$ were used for 15 minutes. Histological sections were incubated with primary antibody (anti-MIB-1, 1:10 dilution) for one hour in humidified chamber and for 15 minutes in blockade phases of endogenous peroxidase, blockade serum ${ }^{2}$, secondary antibody ${ }^{2}$, and streptavidin peroxidase. $\mathrm{DAB}^{2}$ was the chromogen used, with 10-minute incubation. Sections were stained with Harris hematoxylin. Dog skin was used as a positive control. Negative control was obtained by replacing primary antibody by PBS.

All histological sections were stained with HE and were also analyzed regarding clean surgical margins of tumors. Follow-up monitoring was

${ }^{1}$ Ki-67, Imunotech - Marseille, France.

${ }^{2}$ LabVision Corporation - Fremont, CA, USA.

${ }^{3}$ Dako - Carpinteria, CA, USA obtained by reevaluation or telephone conversations with referring veterinarians or dog owners. Animals were followed between one and five years to evaluate neoplasm recurrence rate. However, only 57 dogs could be evaluated because the remaining 25 dogs did not complete the minimum one-year post-tumor-removal period.

Mean and standard deviation were calculated for the following variables: size of neoplastic nodules, number of mitoses/field, mean nuclear diameter, number of NORs/nucleus, and percentage of cells with Ki-67 expression. Data were submitted to analyses of variance using Instat (Graph Pad Software, Version 3.00, 32 Win 95/NT, Created December 23, 1997) and means were compared by the Student-NewmanKeuls test. Chi-square test was employed in order to evaluate the macroscopic presentation as for the number of nodules (simple or multicentric). Differences were considered significant if $\mathrm{P}<0.05$.

\section{RESULTS}

From January $1^{\text {st }} 2000$ to July $31^{\text {st }} 2006,2,678$ canine neoplasms were diagnosed. Skin tumors corresponded to $36.1 \% \quad(n=968)$. Hair follicle neoplasms represented $3.1 \% \quad(n=82)$ of all neoplasms $(n=2678)$ and $8.5 \%$ of all skin neoplasms, corroborating with the results obtained by Bostock (1986), Walder and Gross (1992), and Goorman and Dobson (1995). Trichoblastoma was the most common neoplasia, affecting 32 animals, followed by benign trichoepithelioma $(n=30)$, benign pilomatricoma $(n=7)$, malignant trichoepithelioma $(n=6)$, infundibular keratinizing acanthoma $(n=5)$, and tricholemmoma $(n=2)$. No case of malignant pilomatricoma was diagnosed. Tricholemmoma was not included in the statistical analysis due to its low occurrence. No significant differences were observed when the types of tumor were compared between males $(n=33)$ and females $(n=44)$ and between animals from different age groups. Head, dorsum, and limbs were the most affected sites. The average age of animals was $7.08 \pm 2.14$ years. Poodle dogs were the most frequently affected $(n=21)$, followed by dogs with undefined breed $(n=15)$, and cocker spaniels $(n=10)$. 
The running time from when the tumoral mass was first noticed to its surgical removal was equivalent to $146 \pm 226.87$ days. Mean tumor diameter corresponded to $2.09 \pm 1.64 \mathrm{~cm}$; and there was no significant difference among tumor types. Regarding the number of nodules, trichoblastoma presented a significant higher frequency in the simple form $(\mathrm{P}<0.05)$. The other tumors presented no significant difference between simple and multicentric forms $(\mathrm{P}>0.05)$.
Malignant trichoepithelioma presented a significant higher number of mitoses/field when compared with benign trichoepithelioma and with the other benign tumors of the hair follicle. Trichoblastoma presented a larger number of mitoses/field when compared with the other benign neoplasms. However, the mean diameter of nuclei did not differ between benign and malignant neoplasms (Table 1).

Table 1. Number of mitoses/field, nuclear diameter, number of nucleolar organizing regions (NORs), and percentage of cells with $\mathrm{Ki}-67$ expression $($ mean $\pm \mathrm{SD}$ ) determined in each type of hair follicle neoplasm in dogs

\begin{tabular}{|c|c|c|c|c|}
\hline Neoplasm & $\begin{array}{l}\text { Mitoses/field } \\
(100 \times \\
\text { magnification) }\end{array}$ & $\begin{array}{l}\text { Nuclear diameter } \\
(\mu \mathrm{m})(400 \times \\
\text { magnification })\end{array}$ & $\begin{array}{l}\text { NORs/nucleus } \\
(1000 \times \\
\text { magnification })\end{array}$ & $\begin{array}{c}\text { Percentage of cells } \\
\text { with Ki-67 expression } \\
(1000 \times \text { magnification })\end{array}$ \\
\hline $\begin{array}{l}\text { Trichoblastoma }(\mathrm{n}=32) \\
\text { Benign }\end{array}$ & $5.38 \pm 0.28 \mathrm{~B}$ & $5.76 \pm 0.56 \mathrm{~A}$ & $7.11 \pm 2.24 \mathrm{C}$ & $27.9 \pm 5.03 \mathrm{~B}$ \\
\hline $\begin{array}{l}\text { trichoepithelioma } \\
\qquad(\mathrm{n}=30)\end{array}$ & $1.9 \pm 0.16 \mathrm{C}$ & $6.9 \pm 0.51 \mathrm{~A}$ & $9.26 \pm 3.36 \mathrm{~B}$ & $28.0 \pm 3.99 \mathrm{~B}$ \\
\hline Pilomatricoma $(n=7)$ & $2.3 \pm 0.18 \mathrm{C}$ & $6.04 \pm 0.36 \mathrm{~A}$ & $5.21 \pm 1.34 \mathrm{C}$ & $22.53 \pm 1.86 \mathrm{~B}$ \\
\hline $\begin{array}{c}\text { Malign } \\
\text { trichoepithelioma }(\mathrm{n}=6) \\
\text { Infundibular }\end{array}$ & $18.9 \pm 1.76 \mathrm{~A}$ & $7.3 \pm 0.6 \mathrm{~A}$ & $14.77 \pm 2.49 \mathrm{~A}$ & $49.1 \pm 12.01 \mathrm{~A}$ \\
\hline $\begin{array}{l}\text { keratinizing acanthoma } \\
\qquad(\mathrm{n}=5)\end{array}$ & $2.71 \pm 0.28 \mathrm{C}$ & $6.66 \pm 0.49 \mathrm{~A}$ & $7.37 \pm 1.99 \mathrm{C}$ & $16.0 \pm 3.34 \mathrm{C}$ \\
\hline
\end{tabular}

There was a significant difference in the number of NORs in cells of malignant trichoepithelioma when compared with the others types of neoplasms. Among benign neoplasms, trichoepithelioma presented a significantly higher number of NORs when compared with the other benign neoplasms. In addition to the number and the size of NORs, they also differed between benign and malignant neoplasms (Table 1). Malignant trichoepithelioma presented smaller NORs which were dispersed all around the nucleus, while the other neoplasms presented larger and fewer NORs (Fig. 1).

Ki-67 expression was higher in the malignant trichoepithelioma when compared to benign neoplasms. Among benign tumors, there was no significant difference regarding $\mathrm{Ki}-67$ expression (Fig. 2). The percentage of cells with $\mathrm{Ki}-67$ expression in malignant trichoepithelioma was equivalent to $49.1 \%$, significantly larger than those of infundibular keratinizing acanthoma, pilomatricoma, trichoblastoma, and trichoepithelioma (Tab 1).
Two out of 57 evaluated dogs presented tumor recurrence. One of these presented a benign trichoepithelioma and the other a malignant trichoepithelioma. These two cases were considered recurrences, and at the second biopsy revealed that the site and type of neoplasm found was the same encountered in the first biopsy. No metastasis was found and no animals died. These two cases were the only tumors removed with dirty surgical margins.

\section{DISCUSSION}

The number of NORs was significantly higher in malignant trichoepithelioma cells when compared with the others types of neoplasms. In mammary malignant tumors, the number of NORs is also higher than that in benign neoplasms (Underwood and Giri, 1988; Treré, 1993; Derenzini and Treré, 1994). Malignant trichoepithelioma presented smaller NORs dispersed all around the nucleus, in contrast with benign neoplasms that presented larger NORs, which is in accordance with previous results (Crocker et al., 1989). 

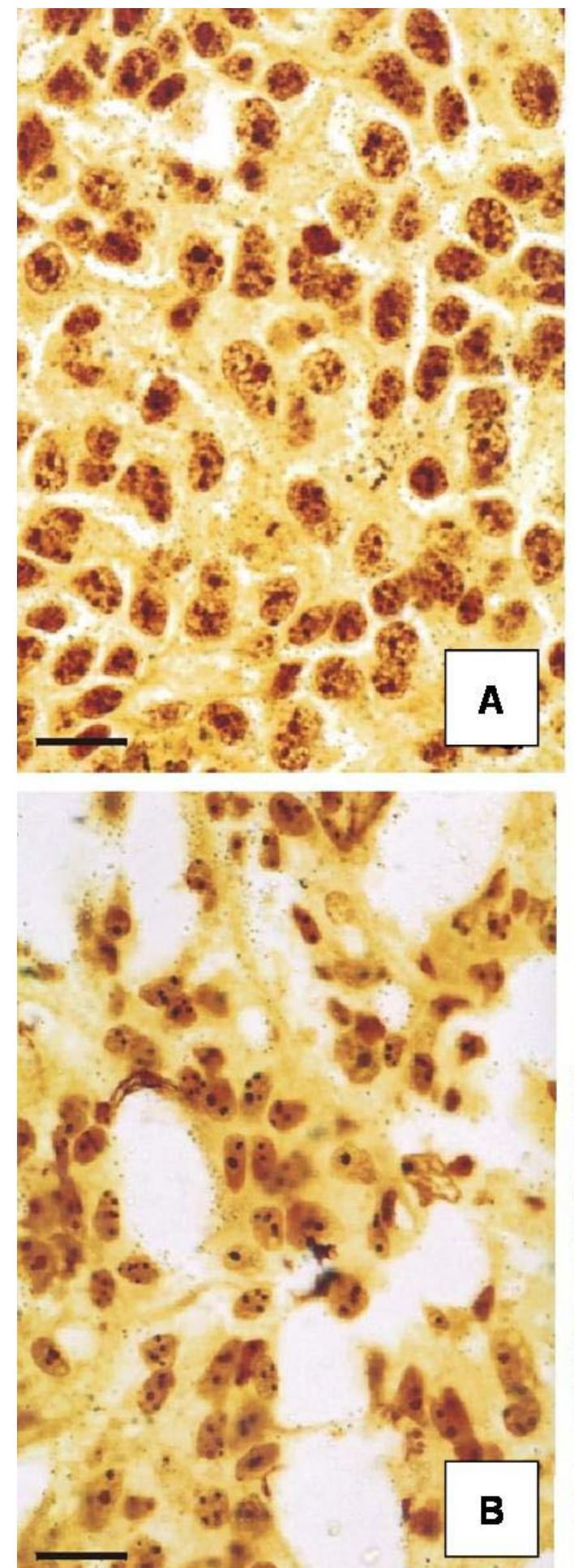
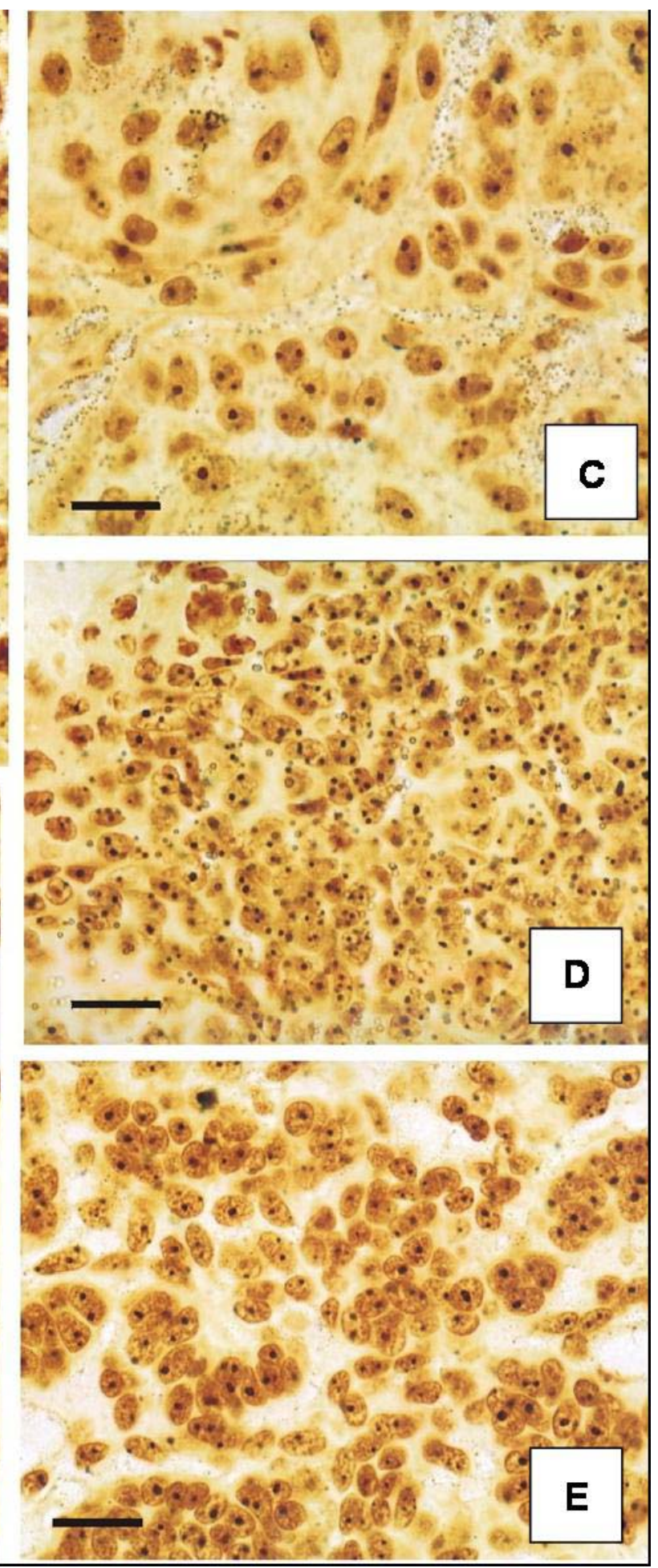

Figure 1. Dog, hair follicle tumor. AgNOR stain. A) Malign trichoepithelioma with a higher count of NORs when compared with benign hair follicle neoplasms. Figure shows smaller sized NORs dispersed throughout the nucleus $(\mathrm{Bar}=16 \mu \mathrm{m})$. B) Benign trichoepithelioma with a higher count of NORs (Bar= $13 \mu \mathrm{m})$ when compared with the infundibular keratinizing acanthoma (C), pilomatricoma (D), and trichoblastoma $(\mathrm{E})(\mathrm{Bar}=16 \mu \mathrm{m})$. 

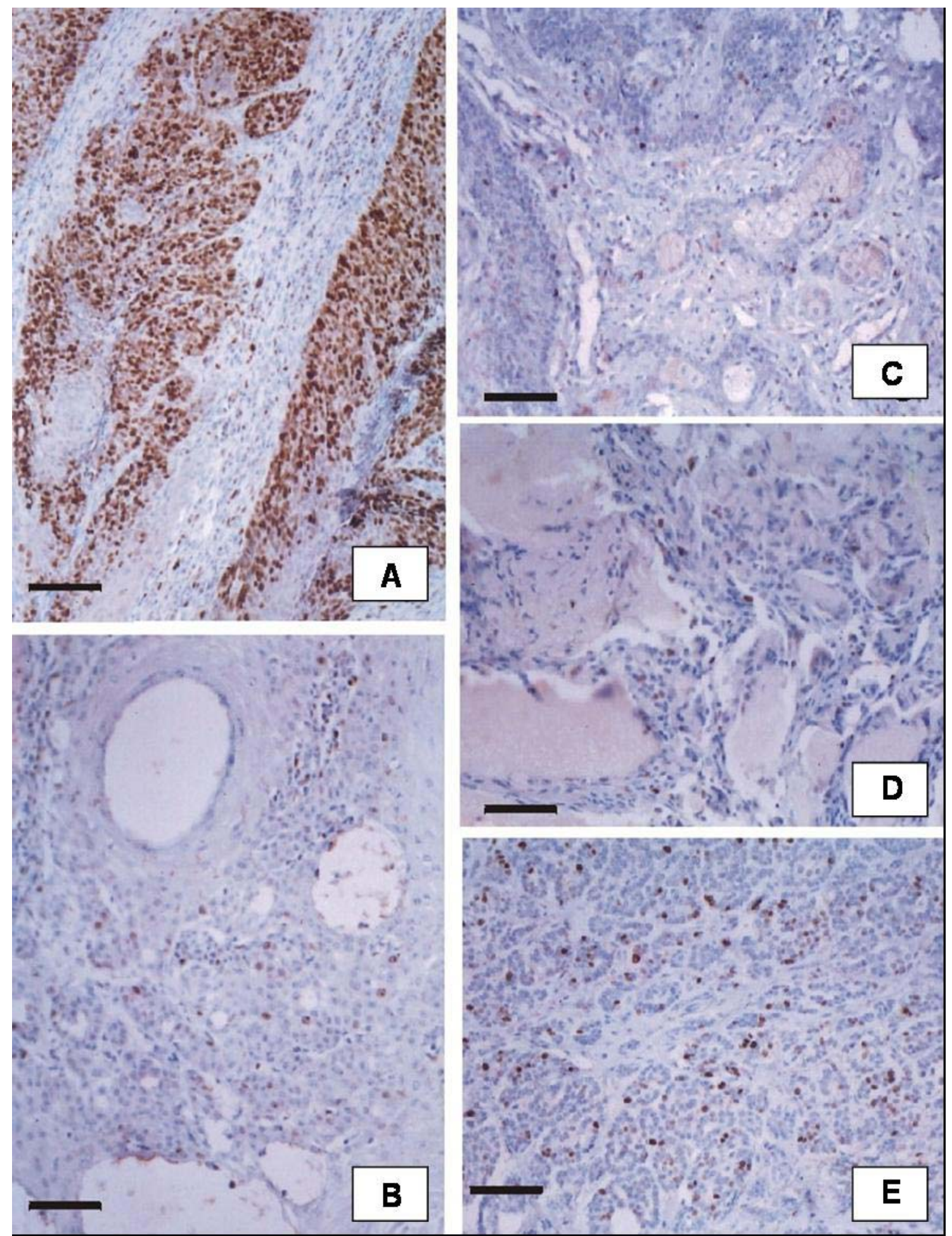

Figure 2. Dog, hair follicle tumor. Streptavidin-biotin-peroxidase, Harris hematoxylin contracoloration $(B a r=13 \mu \mathrm{m})$. A) Malign trichoepithelioma presented higher Ki-67 expression when compared with the benign trichoepithelioma (B), infundibular keratinizing acanthoma (C), pilomatricoma (D), and trichoblastoma (E). 
Ki-67 expression was nuclear. Those cells, whose nuclei presented a brown color, regardless of intensity, were considered positive for immunohistochemistry with anti-MIB-1, while negative cells presented basophilic nucleus. In this study, Ki-67 expression was higher in the malignant trichoepithelioma, when compared to the other hair follicle tumors analyzed, similar to what was observed in mastocytomas of grade III (Seguin et al., 2006), lymphosarcomas (Scase et al., 2006), malignant melanomas (Millanta et al., 2002), spinocellular carcinomas (Della Salda et al., 2002), and malignant tumors of mammary gland (Lohr et al., 1997).

There was no significant correlation between the number of mitoses/field and Ki-67 expression and between the number of mitoses/field and the number of NORs. Results similar to this one were found in other neoplasms (Simões et al., 1994; Greattu et al., 2004; Brunetti et al., 2005). NOR and Ki-67 did not have significant statistic correlation $(\mathrm{r}=-0.5506)$. No significant correlation was observed between NOR and Ki67 in neoplasms of mammary (Ceccarelli et al., 2000), lung (Soomro and Whimster et al., 1990), intestines (Nanashima et al., 1999), and female genital tract (Chung et al., 1994). This may be due to the fact that these methods quantified different phases of cell proliferative activity (Ceccarelli et al., 2000).

The number of NORs has been related to cell proliferation (Derenzini and Treré, 1994; Underwood and Giri, 1988). The higher number of NORs in proliferating cells may be explained by the fact that in G1 phase of the cell cycle, NORs proteins are synthesized. Newly synthesized proteins accumulate in the nucleolus, where they associate with ribosome genes to originate new NORs. The association with NORs proteins induces decondensation of ribosome chromatin, which is required for the next phase of gene duplication (Derenzini and Ploton, 1991). Since NORs are associated with cell proliferation, the technique plays an important role in the prognosis of neoplasms (Treré, 1993).

Nuclear Ki-67 antigen is present in the following phases of the cell cycle: late G1, S, G2, and M, and it is absent in the early G1 phase and G0. It is known that cell cycle is composed of $\mathrm{G} 1, \mathrm{~S}$, $\mathrm{G} 2$, and, M phases. G0 phase is when cells are quiescent but at any time they can start their cycle and therefore start their multiplication process. Phases G1 and G2 are transitional phases, phase $\mathrm{S}$ is when DNA is synthesized and duplicated, and phase $\mathrm{M}$ is when mitosis occurs (Gerdes et al., 1984; Brown and Gatter, 1990).

In humans, several studies have shown the relationship between $\mathrm{Ki}-67$ expression and neoplasms malignity grade (Gasparini et al., 1989; Keshgegian and Canaan, 1995). High Ki67 immunolabeling has been correlated with unfavorable prognosis of several tumors (Veronese et al., 1993; Kerns et al., 1994; Lam et al., 1996). In the present study, recurrence rate of hair follicle tumors might be more related to surgical margins during surgical removal than to Ki-67 expression, number of NORs or mitotic index.

In this study it was observed that the frequency of hair follicle tumor, considering breed, gender, age, and anatomical site, was similar to other results found in the literature (Goldschmidt and Hendrick et al., 2002).

Multicentric neoplasms presented a maximum of six nodules. However, up to 100 nodules may be found in animals affected by infundibular keratinizing acanthoma (Scott et al., 2001). Regarding the mean size of neoplastic nodules, there was no significant difference among the types of hair follicle tumor.

Among benign neoplasms, trichoblastoma presented a larger number of mitoses/field, which is in accordance with the literature (Scott et al., 2001). Malignant trichoepithelioma presented a significantly higher mitotic index when compared with benign tumors; which has been associated with other features of malignity, such as infiltrative growth, which can be observed in the cases of malignant trichoepithelioma analyzed in this study.

However, nuclear diameter did not present significant difference between malignant and benign hair follicle neoplasms, which contrasts with previous results in mammary neoplasms (Lohr et al., 1997). In this study, mammary gland malignant neoplasms presented a larger nuclear diameter than the benign neoplasms. It is imperative to point out that there are no studies regarding nuclear diameter in hair follicle tumors in any other species; humans included. 
In conclusion, malignant trichoepithelioma presented a higher mitotic index, larger number of NORs, and higher Ki-67 expression as compared to benign neoplasms. Trichoblastoma presented larger number of mitoses/field when compared with the benign neoplasms. Trichoepithelioma presented the largest number of AgNORs when compared with the benign neoplasms. Ki-67 expression did not present significant differences among benign neoplasms of the hair follicle. Clean surgical margins are suggested to be more responsible to tumor recurrences than the number of NORs, expression of $\mathrm{Ki}-67$, or the mitotic index.

\section{REFERENCES}

AUBELE, M.; BIESTERFELD. S.; DERENZINI, M. Guidelines of AgNOR quantitation. Zentralbl. Pathol., v.140, p.107$108,1994$.

BOSTOCK, D.E. Neoplasms of the skin and subcutaneous tissues in dogs and cats. Br. Vet. J., v.142, p.1-19, 1986.

BOSTOCK, D.E.; MORIARTY, J.; CROCKER, J. Correlation between histologic diagnosis mean nucleolar organizer region count and prognosis in canine mammary tumors. Vet. Pathol., v.29, p.381-385, 1992.

BOZLU, M.; ORHAN, D.; BALTACI, S. et al. The prognostic value of proliferating cell nuclear antigen, Ki-67 and nucleolar organizer region in transitional cell carcinoma of the bladder. Int. Urol. Nephrol., v.33, p.59-66, 2002.

BROWN, D.C.; GATTER, K.C. Monoclonal antibody Ki-67: its use in histopathology. Histopathology, v.17, p.489-503, 1990.

BRUNETTI, B.; SARLI, G.; PREZIOSI, R. et al. E-cadherin and beta-catenin reduction influence invasion but not proliferation and survival in canine malignant mammary tumors. Vet. Pathol., v.42, p.781-787, 2005.

CECCARELLI, C.; TRERE, D.; SANTINI, D. et al. AgNORs in breast tumours. Micron, v.31, p.143-149, 2000.

CHUNG, T.K.; CHEUNG, T.H.; WONG, F.W. et al. Ki67 and AgNORs staining in squamous cell carcinoma of the cervix: a comparison. Gynecol. Obstet. Invest., v.37, p.127-129, 1994.
CROCKER, J.; BOLDY, D.A.; EGAN, M.J. How should we count AgNORS? Proposals for a standardized approach. J. Pathol., v.158, p.185188, 1989.

DELLA SALDA, L.; PREZIOSI, R.; MAZZONI, M. et al. Cell proliferation patterns in canine infundibular keratinizing acanthoma and well differentiated squamous cell carcinoma of the skin. Eur. J. Histochem., v.46, p.165-172, 2002.

DERENZINI, M.; PLOTON, D. Interphase nucleolar organizer regions in cancer cells. Int. Rev. Exp. Pathol., v.32, p.149-192, 1991.

DERENZINI, M.; TRERÉ, D. AgNOR proteins as a parameter of the rapidity of cell proliferation. Zentralbl. Pathol., v.140, p.7-10, 1994.

GASPARINI, G.; DAL FIOR, S.; POZZA, F. Correlation of growth fraction by KI-67 immunohistochemistry with histologic factors and hormone receptors in operable breast carcinoma. Breast Cancer Res. Treat., v.14, p.329-336, 1989.

GERDES, J.; LEMKE, H.; BAISCH, H. et al. Cell cycle analysis of a cell proliferationassociated human nuclear antigen defined by the monoclonal antibody Ki-67. J. Immunol., v.133, p.1710-1715, 1984

GOLDSCHMIDT, M.H.; HENDRICK, M.J. Tumors of the skin and soft tissues. In: MEUTEN, D.J. (Ed). Tumors in domestic animals. 4.ed. Ames: Iowa State, 2002 p.44-117.

GOORMAN, N.T.; DOBSON, J.M. The skin and associated tissues. In: WHITE, R.A.S. (Ed). Manual of small animal oncology. Gloucester: British Small Animal Veterinary Association, 1995. p.187-200.

GREATTU, W.F.P.L.; AMARAL, A.S.; SILVA, S.B. et al. Proliferation indexes determination by $\mathrm{CEC}$ and $\mathrm{Ki}-67$ in fine needle aspiration cytology of transmissible venereal tumor. Arch. Vet. Sci., v.9, p.53-59, 2004.

HAZAN, C.; MELZER, K.; PANAGEAS, K.S. et al. Evaluation of the proliferation marker MIB-1 in the prognosis of cutaneous malignant melanoma. Cancer, v.95, p.634-640, 2002.

IQBAL, S.; ANDERSON, T.J.; MARSON, L.P. MIB-1 assessments in breast cancers. Breast, v.11, p.252-256, 2002. 
KERNS, B.J.; JORDAN, P.A.; FAERMAN, L.L. et al. Determination of proliferation index with MIB-1 in advanced ovarian cancer using quantitative image analysis. Am. J. Clin. Pathol., v.101, p.192-197, 1994.

KESHGEGIAN, A.A.; CANAAN, A. Proliferation markers in breast carcinoma. Mitotic figure count, S-phase fraction, proliferating cell nuclear antigen, KI-67 and MIB-1. Am. J. Clin. Pathol., v.104, p.42-49, 1995.

KIUPEL, M.; TESKE, E.; BOSTOCK, D. Prognostic factors for treated canine malignant lymphoma. Vet. Pathol., v.36, p.292-300, 1999.

LAM, K.Y.; LAW, S.Y.K.; SO, M.K.P. et al. Prognostic implication of proliferative markers MIB-1 and PC10 in esophageal squamous cell carcinoma. Cancer, v.77, p.7-13, 1996.

LOHR, C.V.; TEIFKE, J.P.; FAILING, K. et al. Characterization of the proliferation state in canine mammary tumors by the standardized AgNOR method with postfixation and immunohistologic detection of KI-67 and PCNA. Vet. Pathol., v.34, p.212-221, 1997.

MILLANTA, F.; FRATINI, F.; CORAZZA, M. et al. Proliferation activity in oral and cutaneous canine melanocytic tumours: correlation with histological parameters, location, and clinical behaviour. Res. Vet. Sci., v.73, p.45-51, 2002.

NANASHIMA, A.; YAMAGUCHI, H.; SHIBASAKI, S. et al. Proliferation of hepatic metastases of colorectal carcinoma: Relationship to primary tumours and prognosis after hepatic resection. J. Gastroenterol. Hepatol., v.14, p.6166, 1999.

ORELL, J.M.; EVANS, A.T.; GRANT, A. A critical evaluation of AgNOR counting in benign naevi and malignant melanoma. J. Pathol., v.163, p.239-244, 1991.

PLOTON, D. Structure and molecular organization of nucleolus. Zentralbl. Pathol., v.140, p.3-6, 1994.

SCASE, T.J.; EDWARDS, D.; MOLLER, J. et al. Canine Mast Cell Tumors: Correlation of Apoptosis and Proliferation Markers with Prognosis. J. Vet. Intern. Med., v.20, p.151-158, 2006.
SCOTT, D.W.; MILLER, J.R.; GRIFFIN, C.E. Muller e Kirk - Dermatologia de pequenos animais [Small animal dermatology]. 6.ed. Philadelphia: WB Saunders 2001. 1528p.

SEGUIN, B.; BESANCON, M.F.; MCCALLAN, J.L. et al. Recurrence rate, clinical outcome, and cellular proliferation indices as prognostic indicators after incomplete surgical excision of cutaneous grade II mast cell tumors: 28 dogs (1994-2002). J. Vet. Intern. Med., v.20, p.933940, 2006.

SILVA, A.E.; SANTO, F.G.A.; CASSALI, G.D. Marcadores de proliferação celular na avaliação do crescimento do tumor sólido e ascítico de Ehrlich. Arq. Bras. Med. Vet. Zootec., v.58, p.658-661, 2006.

SIMÕES, J.P.; SCHONING, P.; BUTINE, M. Prognosis of canine mast cell tumors: a comparison of three methods. Vet. Pathol., v.31, p.637-647, 1994.

SISCHO, W.M.; IHRKE, P.J.; FRANTI, C.E. Regional distribution of ten common skin diseases in dogs. J. Am. Vet. Med. Assoc., v.195, p.752-756, 1989.

SOOMRO, I.N.; WHIMSTER, W.F. Growth fraction in lung tumours determined by $\mathrm{Ki} 67$ immunostaining and comparison with AgNOR scores. J. Pathol., v.162, p.217-222, 1990.

TRERÉ, D. AgNOR quantification in tumour pathology: what is actually evaluated? J. Clin. Pathol., v.46, p.189, 1993.

UNDERWOOD, J.C.; GIRI, D.D. Nucleolar organizer regions as diagnostic discriminants for malignancy. J. Pathol., v.155, p.95-96, 1988.

VERONESE, S.M.; GAMBACORTA, M.; GOTTARDI, O. et al. Proliferation index as a prognostic marker in breast cancer. Cancer, v.71, p.3926-3931, 1993.

WALDER, E.J.; GROSS, T.L. Neoplastic disease of the skin. In: GROSS, T.L.; IHRKE, P.J.; WALDER, E.J., (Eds). Veterinary dermatopathology. A macroscopic and microscopic evaluation of canine and feline skin disease. St Louis: Mosby Year Book, 1992. p.351-373. 